\title{
Sill och potatis till den ena och entrecote till den andra? Individanpassning och likvärdighet på särskilda boenden för äldre
}

TOVE HARNETT \& HÅKAN JÖNSON

Enligt socialtjänstlagen ska äldreomsorgen vara individanpassad och ges utifrån den enskildes behov. Samma lag innehailler ett mål om att socialtjänsten ska främja medborgarnas jämlikhet i levnadsvillkor och kommunallagen anger att kommunen ska behandla sina invånare lika. I denna artikel problematiseras idéer om individanpassning och likvärdig behandling. Dessa olika målsättningar skapar spänningar som får en särskild karaktär påäldreboenden, där måltider och andra aktiviteter ofta genomförs tillsammans med andra och därpersonalens tid delas mellan de boende.

Tove Harnett är filosofie doktor i gerontologi och biträdande lektor vid Socialhögskolan och Centre for Ageing and Supportive Environments (CASE), Lunds universitet.

Håkan Jönson är professor i socialt arbete vid Lunds universitet. Studien har finansierats av Forskningsrådet för hälsa, arbetsliv och välfärd (FORTE anslag: 2013-2296 och 2014-4565).

\section{Introduktion}

Under februari 2014 rapporterade SVT:s Aktuellt om entreprenören Peije Emilssons försök att etablera en ny typ av äldreboenden med högre standard och större valfrihet. Reportaget fokuserade på risken för att denna typ av äldreomsorg skulle 
skapa ojämlikhet och frågan konkretiserades utifrån matsituationen: är det rätt att en person äter falukorv medan en annan på samma boende äter entrecote? Aktuellt intervjuade socialdemokraten Lena Hallengren som menade att detta kändes fel. I tidningsartiklar som kommenterade reportaget fick Hallengren emellertid mothugg av skribenter som menade att möjligheten att välja en dyrare maträtt manifesterade äldres människovärde: "Hallengren - som själv har möjligheten att välja fritt mellan ett näst intill oändligt antal butiker och restauranger - känner alltså att det inte är okej om omsorgsbehövande äldre då och då väljer att sätta guldkant på vardagen"(Rebas, 2014).

Inslaget och kommentaren illustrerar två sätt att tänka om likvärdighet inom äldreomsorgen: som en intern jämförelse med andra personer som har äldreomsorg och som en extern jämförelse med andra personer som inte har äldreomsorg. De två uppfattningarna formulerades emellertid på ett sätt som indikerade tvekan. Hallengren hänvisade inte till någon princip om likvärdighet utan till sin känsla och Rebas uttryckte inte att äldre skulle kunna äta mat av olika standard för jämnan utan "då och då", för att sätta guldkant på tillvaron.

Särskilda boenden för äldre ska ha karaktären av egen bostad, men de boende delar samtidigt ofta sin vardag med andra inom en avgränsad" semiprivat" miljö. Måltider intas ofta gemensamt, aktiviteter på och utanför boendet sker i många fall i grupp. För personer som har hemtjänst blir valet att äta entrecote eller falukorv en privatsak, men på äldreboendet väcks frågor om olikheter mellan personer som äter i samma matrum.

\section{Syfte}

Syftet med denna artikel är att analysera situationer där spänningar mellan individuell och likvärdig omsorg kommer till uttryck inom äldreomsorgens särskilda boenden. Artikeln bygger på deltagande observationer och intervjuer med boende, personal, närstående och enhetschefer på särskilda boenden för äldre. Analysen utgår från följande frågeställningar:

- Vilka slags jämförelser åberopas när äldre personer, personal, chefer och närstående resonerar om vad som betraktas om likvärdig respektive individanpassad omsorg?

- Vilka slags olikheter framställs som acceptabla och vilka olikheter framställs som provocerande?

Artikelns bidrag består i att begrepp och principer som vanligen används på en mer övergripande socialpolitisk nivå undersöks och problematiseras utifrån äldreomsorgens vardag och konkreta genomförande. Studien utgår från en diskurspsykologisk ansats, som betonar att människors ställningstaganden i principiella frågor ofta framstår som motsägelsefulla eftersom de används i relation till olika situationer och ges specifika inramningar (Potter, 1996; jfr Goffman, 1974). Istället för att utgå från hur likvärdig och individanpassad omsorg bör vara, betraktar vi begrepp som individuell och likvärdig som resultat av förhandlingar som bygger på olika typer av jämförelser. 


\section{Interna och externa referenser}

Begrepp som jämlikhet, likvärdighet, rättvisa och orättvisa är definitionsmässigt beroende av jämförelser med andra individer och grupper. Men med vem ska den som bor på ett särskilt boende jämföra sin situation? Frågan kan illustreras av Socialstyrelsens (2011) rapport om särskilda boenden. Rapporten diskuterar rätten till insatser för äldre och yngre personer utifrån olika ambitioner och jämförelser. Medan insatserna till yngre personer med funktionsnedsättningar introduceras med rubriken "Att leva och bo som andra", introduceras insatserna till äldre med "Ett tryggt och värdigt boende" (dvs. likvärdig ersätts med värdig). Yngre ska inte bara bo utan också leva och insatserna enligt LSS, Lagen (1993:387) om stöd och service till vissa funktionshindrade, tar jämförelsegruppen "andra" som utgångspunkt.

En genomgång av funktionshinderpolitiska utredningar visar att det vanligen är personer utan funktionsnedsättningar i samma ålder som avses i diskussioner om rättigheter för yngre personer med funktionsnedsättningar (SOU 1991:46; Jönson \& Taghizadeh Larsson, 2009). Denna typ av jämförelser kommer vi fortsättningsvis benämna externa referenser. Till skillnad från det vi benämner interna referenser hänvisar de till en kategorisering som inte kommer ur en hjälpsituation eller ur själva funktionsnedsättningen.

Är det orättvist om en 80-årig person på ett äldreboende bara får hjälp att komma ut på promenad en gång varannan vecka samtidigt som de flesta andra pensionärer kan gå på promenad varje dag?
Att 80-åringen inte kan promenera oftare har ju att göra med hur samhället stödjer eller hindrar äldre personer med funktionsnedsättningar. Eller ska personer som bor på äldreboenden jämföra sig med andra på äldreboenden? Om ingen på äldreboendet får gå ut oftare än en gång var fjortonde dag är då heller ingen person missgynnad?

Betydelsen av externa referenser kan illustreras med en lagändring i socialtjänstlagen (2001:453) från 2012 (4 kap. lc §) som ger medlemmar av kategorierna "makar" och "varaktigt sammanboende" rätt att flytta tillsammans till särskilt boende även om endast den ena maken har behov av insatsen. Tidigare saknades den rättigheten. De folkpartistiska riksdagsmän som krävde ändringen gjorde detta med argumentet att "det är inte kommunernas sak att avgöra när det är dags för makar att skiljas åt" (Björklund \& Westerholm, 2009). Kraften i den externa jämförelsen ligger i möjligheten att ifrågasätta oförmågan att tillhandahålla parlägenheter med frågan: så du tycker att det är kommunens sak att avgöra när det är dags för makar att skiljas åt?

\section{Äldreomsorg och individanpassning}

Att äldreomsorgen ska vara individanpassad är ett av de starkast uttryckta målen inom både svensk äldrepolitik och internationell omsorgsforskning. Socialtjänstlagens portalparagraf (2010:427) anger att äldreomsorgens hjälpinsatser ska ges med respekt för den enskildes självbestämmande och i 5 kap. $5 \S$ framgår att: "Den äldre personen ska, så långt det är 
möjligt, kunna välja när och hur stöd och hjälp i boendet och annan lättåtkomlig service ska ges." En genomgång av sociallagstiftningen som Szebehely och Trydegård (2014) genomfört visar också att den enskildes rätt att påverka och välja omsorgsinsatser utifrån sina behov och sina ekonomiska förutsättningar har förstärkts under de senaste 20 åren.

Också inom omsorgs- och omvårdnadsforskning har rätten till ett individanpassat omhändertagande blivit en central komponent, bland annat inom normativa modeller med benämningar som "person centered care" (McCormack, Roberts, Meyer, Morgan, \& Boscart, 2012), "relationship centered care" (Nolan, Davies, \& Brown, 2006) och "culture change" (Koren, 2010). Omsorgen om äldre ska, enligt företrädare för dessa modeller, ha en holistisk karaktär där personen - och dennes önskemål och behov - ställs i centrum. Internationellt används också begreppet "personalization" för att uttrycka denna strävan efter ett individuell omhändertagande (Berglund, 2007). Den personcentrerade omsorgen har ställts upp som alternativ till ett omhändertagande som fokuserar specifika (medicinska) uppgifter (Edvardsson, Winblad, \& Sandman, 2008; McCormack et al., 2012; Noddings, 1999). Målet om att tillhandahålla en individanpassad äldreomsorg har beskrivits som en etisk utmaning, besläktad med målet om att upprätthålla omsorgstagarens autonomi (Bolmsjö, Sandman, \& Andersson, 2006; Suhonen et al., 2011). Utmaningen består då inte bara i att undvika ett rutiniserat, manualbaserat och medikaliserat omhändertagande, utan också i att få kunskap om vem personen är och vad personen vill i de fall då det på grund av demenssjukdom är svårt att få kunskap från den enskilde (Harnett \& Jönson, 2010).

\section{Äldreomsorg och likvärdighet}

Principen om att alla människor har lika värde och därför ska behandlas likvärdigt är central inom vårt samhälle där den bland annat återfinns i FN:s deklaration om de mänskliga rättigheterna (artikel 1 , 2, 7,22, 25). Likvärdighet kan ses både som ett mål och ett förhållningssätt. En skrivning om likvärdighet som ett mål återfinns i socialtjänstlagen, där det i portalparagrafen framgår att socialtjänsten ska "främja jämlikhet i levnadsvillkor". Socialtjänstens verksamheter får alltså inte medverka till att ojämlikhet befästs.

När det gäller likvärdighet som förhållningssätt finns den så kallade likabehandlingsprincipen i kommunallagen (1991:900), där 2 kap. $2 \S$ anger att "Kommuner och landsting skall behandla sina medlemmar lika, om det inte finns sakliga skäl för något annat". Här finns det också en koppling till begrepp som rättvisa, orättvisa och diskriminering. Diskrimineringslagen $(2008: 567,4$ §) definierar diskriminering som ett fall där någon missgynnas genom att behandlas sämre än någon annan behandlas i en jämförbar situation, om missgynnandet kan hörledas till de kategoriella tillhörigheter lagen skriver om (kön, etnicitet, ålder etc.). Vad som betraktas som en jämförbar situation för en person som bor på ett äldreboende är, som framgått inledningsvis, emellertid inte självklart. 
Frågan om likvärdighet har teoretiserats och undersökts i analyser av medborgarskap och sociala rättigheter (Rawls, 1971), medan det angränsande begreppet jämlikhet har undersökts i relation till socialpolitik och välfärdssystem (Vabø \& Szebehely, 2012; Szebehely \& Trydegård, 2014). I förhållande till äldreomsorgens praktik har begreppet likvärdighet dock inte haft någon central betydelse. Likvärdighet som förhållningssätt kan uppfattas stå i konflikt med en omsorg som baseras på individens behov. Omsorgsforskare som Noddings (1999) menar att den politiska filosofins likvärdighetsprincip inte är tilllämpbar inom den typ av arbete som äldreomsorg utgör. Omsorgsinsatser bygger på mänskliga relationer och kan inte guidas av den anonymisering som enligt Rawls (1971) ska motverka särbehandling utifrån klass eller social position. Rangordningen mellan individanpassning och likvärdighet synliggörs i både kommunallagen och diskrimineringslagen, där olikhet $\mathrm{i}$ behov utgör "sakliga skäl" för olikhet i behandling och där situationen för två individer med olika behov inte anses "jämförbar".

\section{Studiens teoretiska verktyg}

Vår analys hämtar sina verktyg från referensgruppsteorin, enligt vilken individer använder så kallade referensgrupper för att avgöra vad som är normalt och rättvist (Merton \& Kitt, 1950). Inom teorin görs en åtskillnad mellan referensgruppers normativa och komparativa funktioner och mycket av den forskning som använder teorin har handlat om hur individer anpassar sitt framträdande till grupper de identifierar sig med. Den komparativa funktionen har senare kommit att utgöra navet inom teorin om relativ deprivation, det vill säga en teori som anger att ojämlikhet och orättvisa upplevs utifrån jämförelser inom och mellan grupper (Runciman, 1966, s. 9): "people's attitudes, aspirations and grievances largely depend on the frame of reference within which they are conceived." Just dessa referensramar är av intresse. Vilka referenser åberopas för att avgöra vad som är individanpassad och likvärdig omsorg?

I artikeln kommer vi att diskutera tre typer av referenser som vi benämner kategoricentrerade, kontextcentrerade och personcentrerade. Dessa har identifierats utifrån referensgruppsteorin, genomgångar av forskning om hjälp- och omsorgsrelationer, samt analys av empirin till denna studie.

De tre referenserna kan i sin tur vara interna eller externa, där interna referenser hänvisar mot omsorgssituationen och funktionsnedsättningen, medan externa referenser hänvisar mot kategorier, kontexter och personcentrerade aspekter som är oberoende av omsorgsarrangemang och funktionsnedsättningar. Ett försök att åstadkomma en individanpassad omsorg genom att ta fasta på personens livshistoria kan alltså ses som en extern personcentrerad referens, medan en kommentar som hänvisar mot andra omsorgstagare är ett exempel på en intern kategoricentrerad referens. Den som liknar äldreboendets matrum vid en restaurang använder en extern kontextbaserad referens som aktualiserar en uppsättning externa kategorier-matgäster, serveringspersonal. 
Figur I: Det empiriska materialet

\begin{tabular}{l|llll}
\hline & Västergården & Östergården & Norrgården & Södergården \\
\hline Boende & I par* & 2 grupp & I grupp & I grupp \\
& 3 enskild & I enskild & I par & \\
Personal & 2 grupp & I grupp & I grupp & I grupp \\
Närstående & & I par & I grupp & \\
Chef & I enskild & I enskild & I enskild & I enskild \\
\hline
\end{tabular}

* Med par menas att två personer intervjuades tillsammans.

\section{Metod}

Studien har genomförts inom ramen för ett större forskningsprojekt och analysen bygger på delar av det material som samlats in till detta. Projektet är godkänt av regionala etikprövningsnämnden och datainsamlingen genomfördes från september 2013 till april 2014. Det material som används i denna studie utgörs av 21 intervjuer, med totalt 45 intervjupersoner bestående av äldre, närstående, enhetschefer och personal vid fyra kommunala äldreboenden, samt deltagande observationer vid två av boendena. De fyra äldreboendena var lokaliserade i eller i utkanten av två medelstora svenska kommuner. Intervjuerna var semi-strukturerade och innehöll temafrågor och fem vinjetter där intervjupersonerna fick resonera om vad som menas med individuell och likvärdig omsorg.

Vinjetterna, vilka presenteras i detalj i nästa avsnitt, avsåg att illustrera spänningar i relation till frågor om normalitet, individanpassning, likvärdighet och orättvisa. I denna studie har två av vinjetterna används som underlag. Syftet med vinjetterna var att få del av resonemang om principer och samtidigt stimulera inter- vjupersonerna till att utveckla beskrivningar utifrån personernas konkreta vardag.

Gruppintervjuerna varade mellan 50 och 70 minuter medan de individuella intervjuerna varade mellan 30 och 60 minuter. Deltagande observationer genomfördes vid totalt 19 tillfällen vilket innebär cirka 100 timmars observationer. Observationerna genomfördes på olika tider på dygnet och på både helger och vardagar. Dock gjordes inga observationer under natten (dvs. mellan 21 och 07). Observationerna genomfördes på två avdelningar där det var möjligt att inhämta informerat samtycke från de boende. Vardagen som observerades kan därför inte ses som representativ för situationen på landets äldreboenden.

Under observationerna följde vi Emerson, Fretz och Shaws (1995) tillvägagångssätt genom att observera "scener". Istället för att försöka fånga allt som pågick lade vi fokus på att observera kortare episoder av vardaglig interaktion. Under observationerna vistades vi i allmänna utrymmen, så som dagrum, matrum och korridorer (förutom vid de tillfällen då någon av oss blev inbjuden till en privat lägenhet av de boende själva). De scener som obser-

Harnett \& Jönson: Sill och potatis till den ena och entrecote till den andra? 
verades utgjorde vardagliga händelser som exempelvis småprat om TV-program, äldre som klagar på maten och aktiviteter så som gymnastik och frågesport. Även om studiens resultat huvudsakligen illustreras genom intervjucitat, så baseras analysen på både fältanteckningar och intervjumaterial.

Analysen av det empiriska materialet guidades av principerna för "analytic bracketing" (Gubrium \& Holstein, 1997). Detta innebar att vi växelvis fokuserade på frågan om vad och hur. Inledningsvis fokuserade vi på vad som konstruerades som likvärdigt eller individuellt och satte samtidigt frågan om hur inom parantes. Därefter fokuserade vi på frågan om hur olika slags arrangemang konstruerades som antingen likvärdiga eller individuella. I hur-delen av analysen användes referensgruppsteorin som analytiskt verktyg och tre typer av referenser utkristalliserade sig: kategoricentrerade, kontextcentrerade och personcentrerade. Dessa referenser skapade i sin tur olika inramningar beroende på om de konstruerades som externa eller interna jämförelser.

\section{Vinjetterna}

För att besvara studiens syfte har vi i vår analys koncentrerat oss på två av vinjetterna och de diskussioner som följde. Den första vinjetten var formulerad enligt följande:

Vinjett A: Signes dotter är missnöjd över att omsorgstagarnas kontaktpersoner lägger upp sitt arbete på så olika sätt. Kontaktpersonerna till två andra boende har gått samman och gör utflykter till museum en gång var 14:e dag. Dottern säger att Signe också skulle tycka att det vore roligt att komma med, men kontaktpersonerna säger att de två som åker ihop är väninnor och därför kan Signe inte följa med.

Vinjetten är utformad så att det är möjligt att utgå från olika slags jämförelser i diskussionen om huruvida Signe ska få följa med eller inte. Kan äldreboendet möjliggöra att två väninnor åker på sina egna aktiviteter eller medverkar boendet i detta fall till att en person lämnas utanför en rolig aktivitet? Om de två väninnorna hade bott grannar i ett hyreshus, eller till och med i ett kollektivboende, hade det framstått som normalt att de kunde åka på en utflykt tillsammans, utan ytterligare grannar eller väninnor.

Även den andra vinjetten var formulerad utifrån tanken att flera slags jämförelser ska vara möjliga:

Vinjett B: Signes son tycker det är viktigt att hans mor får lite guldkant på vardagen, även om hon bor på ett äldreboende. Varje vecka köper han vitt vin och räkor som han ber personalen att ge henne på fredagen. Han är noga med att hans mamma ska få äta gott varje dag och köper därför goda ostar och fin salami till hennes smörgåsar. Birgit, som sitter mittemot Signe i matrummet, har på senare tid klagat på att hon aldrig får några goda pålägg på sina mackor. 
Figur 2.

Modell för jämförelser i resonemang om individuell och likvärdig omsorg

\begin{tabular}{|l|l|l|}
\hline Typ av referens & Internt orienterad & Externt orienterad \\
\hline Kontextcentrerad & Omsorgskontexten & Andra kontexter \\
\hline Kategoricentrerad & $\begin{array}{l}\text { Andra omsorgstagare, funktions- } \\
\text { nedsättningen }\end{array}$ & Andra kategorier \\
\hline Personcentrerad & $\begin{array}{l}\text { Den unika personen i relation till } \\
\text { omsorg eller funktionsnedsättning }\end{array}$ & $\begin{array}{l}\text { Andra aspekter av den unika } \\
\text { individen }\end{array}$ \\
\hline
\end{tabular}

Signes son skulle utan vidare kunna köpa goda ostar och salami till sin mor om hon bodde hemma, men är det acceptabelt att han gör det när hon bor på ett äldreboende? Och kan hon äta sina smörgåsar i boendets matrum?

\section{Resultat}

Resultaten är uppdelade utifrån vilka slags jämförelser som åberopas när olika aktörer resonerar om vad som betraktas som likvärdig respektive individanpassad omsorg. Vidare visar resultaten hur dessa jämförelser skapar olika logiker för framställningen av olikheter mellan olika omsorgstagare. Studien åskådliggör att beroende på vilka jämförelser som åberopas så kan olikheter beskrivas som antingen önskvärda, acceptabla eller provocerande och oacceptabla.

\section{Olikheter som något önskvärt och normalt}

Samtliga intervjupersoner menade att vissa olikheter i behandlingen av de boende kunde ses som något önskvärt. Genom att utgå från jämförelser utifrån situationer utanför äldreboendet framställdes olikheter mellan människor som något normalt och i omsorgskontexten beskrevs olikheter som ett tecken på att äldreboendet anpassade sig till individen och inte var en plats där alla stöptes i samma form.

På de fyra äldreboendena fanns det olika slags möjligheter för de äldre att använda sina egna pengar för att köpa mat, frukt eller godis för eget bruk. Några av äldreboendena låg nära en affär och då kunde personalen följa med de äldre och handla i mån av tid. I andra fall var det kontaktpersonen eller en närstående som hjälpte de äldre att handla. Dessutom fanns det på samtliga boenden ett system med en trivselkassa där de boende varje månad kunde lägga en mindre summa pengar (ca 100 kronor) som användes till gemensamma inköp av pizza, vin och liknande.

I de resonemang som följde Vinjett B, där Signes son köper räkor och goda pålägg till sin mor, uttryckte ingen av intervju- 
personerna att det var fel av sonen att köpa med sig godsaker till sin mamma. Tvärtom, sågs hans handlande som berömvärt och det var bra att de boende unnade sig något extra. Samtliga intervjupersoner menade att det var oproblematiskt om Signe åt inköpta godsaker i sin egen lägenhet. Chefer och personal menade att det också var relativt oproblematiskt att äta godsaker i det gemensamma matrummet.

I en gruppintervju med personal på Västergården framställde personalen den situation som beskrevs i vinjett $B$ som acceptabel genom åberopandet av en extern kontextcentrerad referens. Nadja, en undersköterska, jämförde Signes situation i äldreboendets matrum utifrån en extern kontext - en restaurang - där det ses som självklart att folk äter olika slags mat:

Men annars är det ju ändå så här att man betalar en summa för en rätt och det är en viss sak som ingår och lite utöver det vanliga så får man ju köpa det själv, helt enkelt. Precis som när man köper en Dagens ute. Där ingår vissa saker, men allting ingår inte. Vill du ha ett wienerbröd till får du kanske betala extra för det. Det är ju lite så här också. Att allt kan ju inte ingå. Det kan ju bli tjugo sorters pålägg varje dag. Det funkar inte (Nadja, omsorgspersonal).

När måltidssituationen på äldreboendet likställdes med "när man köper en Dagens ute" skapades också en kategoricentrerad extern jämförelse mellan "kunden" i äldreboendets matrum och en kund på en restaurang. Folk i allmänhet väljer själva vad de kostar på sig på restaurang.

En jämförelse mellan matrummet och en restaurang introducerar nya sorters krav på äldreboendet. En fältanteckning från Västergården illustrerar hur en av de boende använde denna typ av jämförelse för att ifrågasätta personalens sätt att koka hans frukostägg:

Jag och Ove pratar om frukosten. Han pratar om äggen och att personalen ofta kokar dem för länge:

"Man kan ha två varianter, de har de ju på hotellrestauranger", säger Ove. Han säger att på hotell brukar de dels ha ägg som är kokta sju minuter och dels ägg som är kokta i tolv minuter eller så (fältanteckning från Västergården).

Under observationerna återkom Ove vid flera tillfällen till sitt missnöje över att personalen inte lyckas koka hans ägg på det sätt han förväntat sig och jämförelsen med restaurangen underströk rimligheten i hans klagomål. Oves jämförelser med den externa kontexten gjorde det möjligt att utmana villkoren för frukosten på boendet, men aktualiserade samtidigt en relation som omsorgspersonalen i några fall uppfattade som provocerande-att de som serveringspersonal ska passa upp på gästen.

Medan personal och chefer beskrev det som normalt att de boende åt egeninköpt mat i matrummet, upplevde flera av de boende detta som något provocerande. Bara under en intervju med boende uttrycktes acceptans för att personer åt egna godsaker i det gemensamma matrummet. Efter att först ha beskrivit detta 
som ett problem, nämnde en av de boende på Norrgården, Artur, att flera på avdelningen faktiskt hade särskilda pålägg som rökt lax vid frukosten och ingen verkade reagera särskilt över det. På intervjuarens fråga om detta ändå inte kunde väcka avundsjuka svarade intervjupersonerna:

Arthur (boende): Ja, det vet vi väl inte. Inger (boende): Nej, det tror jag inte egentligen, inte vi vuxna, vi är inga barnungar. Nej, det är vi inte så jag tror inte det.

Arthur (boende): Nej, var och en får göra sitt.

Med detta anknöt Inger till en typ av resonemang som fördes bland personal om att olikheter i matsituationen var något som människor måste kunna acceptera. Inger åberopade en extern jämförelse med två ålderskategorier - tillhörighet $\mathrm{i}$ kategorin "vuxna" ställdes i kontrast till kategorin "barnungar". Utifrån jämförelsen med andra vuxna, framstod det som logiskt att de som bor på äldreboenden måste acceptera att personer runt bordet äter olika mat. Detta resonemang står i kontrast till resonemang som bygger på interna referenser där omsorgstagarna jämförs med varandra och där olikheten dem emellan blir något oacceptabelt.

\section{Olikheter som utvecklingav personligheten}

I förarbetena till det kapitel i socialtjänstlagen som handlar om äldres rätt till ett värdigt liv betonar regeringen att den som får omsorg ska kunna leva utifrån sin identitet och personlighet. Som del i detta ingår att individen bör få stöd att "behålla sina intressen och vanor, men även i vissa fall att bryta ett mönster av vanor" (2009/10 SoU:18, s. 9). Det är också vanligt att beskrivningar av äldreomsorgen betonar vikten av att bevara omsorgstagarens identitet och motverka förändring som beror på omsorgenskontextens interna villkor (Harnett \& Jönson, 2010; Erlandsson, 2014).

Ett återkommande tema när personal diskuterade individanpassad omsorg $i$ våra intervjuer var att de äldre skulle få leva som de gjort förut. Ett exempel på hur denna externa personcentrerade referens användes gav personalen vid Södergården:

Vi gör en plan utifrån hur deras liv har sett ut, hur de har levt innan de kom hit här. Och sedan ska man ju inte behöva ställa om sig. Vi anpassar oss efter individen (Lina, omsorgspersonal).

När intervjupersonerna pratade om individanpassning handlade det ofta om äldres morgonvanor, till exempel om flexibilitet $\mathrm{i}$ fråga om när de äldre ska stiga upp, när de ska äta frukost och om de ska äta i matrummet eller i den egna lägenheten. Det var också vanligt att personal och enhetschefer förde diskussionen utifrån en förändring mot förr, då boendets rutiner reglerade vardagen. Anton, personal på Västergården, beskrev att de äldre tidigare var tvungna att stiga upp vid samma tid, men att det inte alls fungerar så idag. I intervjun förklarade Anton att om han knackade på hos någon äldre som ville sova vidare så sade han numera bara:"Jaha, 
hej då, ring när du vaknat”. Individanpassningen rättfärdigades också med hänvisning till en extern referens till kontext och kategori: de boendes rum var deras lägenheter och de själva var därmed hyresgäster. I några intervjuer användes denna jämförelse för att underbygga påståenden om att personal hade stört boendes privatliv. Exempelvis berättade en närstående att han hade besökt sin moder och plötsligt stod det en personal i rummet, som kommit in utan att knacka. "Så gör man ju inte i en vanlig bostad", menade han.

Den individanpassning som gällde de äldres morgonvanor var också synlig under våra observationer. På Östergården gled frukosten för vissa boende ibland över $i$ förmiddagsfikat, som serverades klockan 10.30. På Västergården åt de boende frukost mer samlat vilket delvis berodde på att de hade en större gemenskap i matrummet. Vid ett tillfälle kommenterade den personal som gjorde i ordning i köket på Västergården att "på den här avdelningen väljer vårdtagarna att äta samlat, men det är mer utdraget på andra sidan”. Hon verkade med detta vilja parera risken att observatören skulle tro att den samtidiga frukosten styrdes av äldreboendets rutiner.

Referenser till de boendes skilda personligheter och önskemål användes också i kommentarer om olikhet i matvanor. Under en gruppintervju med personalen på Södergården ledde vinjetten om Signes mat till resonemang om att vissa av de som klagade på skillnader i matvanor inte ville ha bättre pålägg när de själva var tvungna att betala. De som klagade var alltså inte berövade möjligheten att själva bekosta lyxig mat och klagomålen ramades därför in som något annat än ojämlikhet. Under diskussionen kommenterade Anne också den positiva förändring som skett med en av de boende som numera åt lyxig mat:

Anne (omsorgspersonal): Ja, men för Rolf, han äter ju lax och brieost och det. Men när han flyttade in för ett år sedan, då åt han leverpastej och kantfria smörgåsar med Lidl:s saltgurka. Det var viktigt att det skulle vara Lidl:s då. Sen bjöd vi honom. Vi hade köpt in brieost och så sa vi:"Men, prova den här. Den här tror jag du skulle tycka om?" Och sedan dess har han ätit brieost med tomater och sedan är det lax i alla dess former. Så nu tycker sonen att han blivit en liten gourmetgubbe. För från det att han har ätit smörgåsar i flera herrans år, så nu är det liksom lite ditt och datt han...

Sofia (omsorgspersonal): Det är inte bara den här leverpastejen.

Anne (omsorgspersonal): Utan han har ju liksom ändrat sig. Och det är ju faktiskt väldigt kul.

Anne berättade att det var personalen som handlade till Rolf och att Rolf själv sade till när han behöver något. Exemplet med Rolf visar att personal kan tänka sig att medverka till att vissa boende äter lyxig mat medan andra äter enkel, det vill säga en situation som kommenteras i rubriken till denna artikel. Beskrivningen av hur Rolf utvecklats till en gourmetgubbe gav dock den lyxiga maten en annan innebörd än den som fallbeskrivningen med Signe aktualiserar. Det var personalens kännedom om just Rolf som gett upphov 
till förslaget om att han skulle prova brieost. Rolfs förändring ramades in som en del i hans personliga utveckling inom omsorgskontexten. Exemplet visar på en spänning som finns mellan externa och interna referenser till individens personlighet över tid, där risken att förneka behov av och möjligheter till förändring av personen står mot risken att förändringen egentligen styrts av omsorgskontextens villkor (Harnett \& Jönson, 2010).

Det som är av intresse i vår analys är hur omsorgens potential att hjälpa människor till utveckling genom att exempelvis "bryta ett mönster av vanor" samtidigt kan användas för att framställa olikhet som något annat än ett exempel på ojämlikhet.

\section{Olikhet som hot mot likvärdighet och gemenskap på boendet}

Det fanns emellertid konkurrerande sätt att rama in de olikheter som uppstod i fallet med Rolfs nya matvanor. En annan intervjuperson, Sara, menade att det var "konstigt" om en åt lax och räkor och en annan "något äckligt". Till skillnad från resonemang som utgick från externa referenser, där olikheter sågs som normalt eller till och med önskvärt, så framstod olikheterna som problematiska när resonemangen byggde på interna referenser. I citatet nedan skildrar undersköterskan Sara Rolfs matvanor utifrån den interna omsorgskontexten:

Men det gör de ju uppe hos oss. De handlar ju själva och passar inte pålägget, då kommer de ju ut... Jag handlar ju till Rolf. Och han har oftast rökt, gravad lax och brieostar och mögelost och vad han nu ska ha på sina rostade mackor. Och de kan ju se lite konstigt ut. Till kvällen, men [Intervjuaren: Konstigt ut?] Ja, men om du serverar varm potatissoppa och så äter de då lingongrova eller knäckebröd och så ligger det ost och skinka framme och så sitter han där med rostade mackor och så har han brieost med tomater och så lite gravad lax på den mackan (Sara, omsorgspersonal).

Medan Sara beskrev det som ett hot mot likvärdigheten om någon äter lax och räkor och andra äter "något äckligt", lyfte dock en annan undersköterska, Anne, fram att de boende brukade bjuda varandra på maten: "... men de bjuder ju gärna. Alltså, om det är någon som säger 'gud vad det där ser gott ut'. Så 'var så god, det finns på bänken" (Anne, omsorgspersonal). Att bjuda andra skildrades som ett sätt att lindra problemet med olika mat i matrummet och utgjorde samtidigt en hänvisning till en positiv gemenskap mellan de boende. Referenserna var $\mathrm{i}$ detta fall interna i bemärkelsen att både problemet och lösningen lokaliseras till äldreomsorgens praktik.

I flera intervjuer leddes frågan om olikhet i matvanor över till en diskussion om den så kallade "trivselkassan" som kunde användas för att skapa en festligare situation för alla och därmed jämna ut olikheterna mellan boende. Till exempel beskrev personalen att de provat att använda pengar från de boendes gemensamma kassa till att köpa några goda ostar till alla på avdelningen. 
Under intervjuerna var de boende och närstående som regel mer negativa till Signes matvanor, jämfört med enhetschefer och personal. De boende uppfattade inte själva maten som något problematiskt. Laddningen låg i det att den lyxiga maten konsumerades i matrummet, så att en person vid samma bord uppfattade situationen som orättvis. Handlingen drabbade en annan person. Bland närstående och boende uttrycktes relativt unisont att Signe borde äta det sonen gav henne på rummet och i många fall tog de intervjuade ganska starkt avstånd från handlandet. Samtidigt kommenterades frågan som ett "i-landsproblem" eller med uttryck som "Ja det var ju också ett problem". Flera boende gav exempel på hur de själva eller närstående brukade agera, vilket ett citat från Gunhild på Östergården kan exemplifiera:

Om jag är inne på mitt rum och min son säger "jag ska bjuda på det idag" då kan man sitta på sitt eget rum och både äta och dricka det och ingen annan har ont av det. Det är inte lätt att sitta mittemot en som äter gott och inte få någonting (Gunhild, boende).

I samtliga grupper kommenterades svårigheter bland många boende att förstå att maten var privat, samt att boende som av olika orsaker redan kände sig utsatta eller exkluderade kunde må särskilt dåligt av olikheten.

I flera fall kommenterades Signes agerande $i$ vinjett $B$ som olämpligt eftersom det utgjorde ett brott mot vett och etikett inom en social gemenskap. I en gruppin- tervju med boende uttryckte intervjupersonen Elsa detta som att "så gör man ju inte normalt, sitter och plockar i sig något gott själv och låter andra titta på... det gör man ju bara inte". I detta fall åberopades en extern jämförelse som handlar om allmänna sociala normer: vi förväntas bjuda andra i vår närhet om vi har något gott. I likhet med flera andra boende och närstående jämförde Elsa med födelsedagsfiranden där alla bjuds på tårta. Enhetschefen Susanne beskrev också hur bjudandet på Södergården hade ritualiserats så att olika personer turades om att bjuda varandra på whisky och likör. Här kan bjudandet tolkas som ett uttryck för att de normer som gäller i samhället i övrigt också gäller på äldreboendet, där de fogats in i en positiv gemenskap.

Med referensen till dessa normer blev Signes agerande en fråga om dåligt omdöme. I intervjuer med boende på Östergården förekom klagomål över att vissa på boendet skröt genom att visa upp presenter som de hade fått från närstående eller kommentera hur ofta närstående hörde av sig. I anslutning till diskussionen om lyxig mat menade Arthur på Norrgården att "en del människor har behov av att göra sig märkvärdiga". Med detta omformulerades förekomsten av lax och brieost i matrummet från en fråga om social ojämlikhet till en fråga om brist på hänsyn och social oförmåga där boende försökte höja sin status genom konsumtion och skryt.

\section{Den sociala ojämlikheten som hot}

Som tidigare nämnts, bedömdes det som problematiskt med olikheter som "drabbade" andra och att personalen 
bidrog till att skapa olikheter som handlar om status och klass, vilket en intervju med närstående på Norrgården kan exemplifiera:

Det är klart att den fattige ska få lika god mat som de andra; man ska inte behöva sitta och titta på när andra äter bakelser. Inte sill och potatis till den ena och entrecote till andra. Sådana saker måste vara likvärdiga (Ida, närstående).

Utifrån en jämförelse till externa kategorier av medborgare är det en självklarhet att en person med hög inkomst som bor hemma kan välja att äta entrecote, medan en person med låg inkomst som också bor hemma kanske äter sill och potatis. Vad personer med olika inkomster väljer att äta för mat betraktas som en privatsak så länge de bor hemma. Om personerna bor på ett äldreboende, däremot, kan situationen ramas in utifrån den interna omsorgskontexten och olikheterna framstår då som ett hot mot likvärdigheten. Det citatet ovan exemplifierar, antyddes eller uttrycktes i flera av våra intervjuer. Arrangemang som upprätthöll eller förstärkte social ojämlikhet på äldreboendet kunde inte accepteras.

I den intervju med boende där Signe och Arthur beskrev lyxiga pålägg som acceptabla med hänvisning till att de var "vuxna", frågade intervjuaren om man kunde tänka sig att närstående betalar lite extra för att personalen exempelvis skulle sitta och läsa med en förälder. Detta tog samtliga fyra intervjupersoner ställning emot. Intressant nog, formulerade de sam- tidigt om frågan från att avse om att man skulle kunna "få" extra omsorg till att man skulle "behöva betala" för den. Detta antyder farhågor om att möjligheten att köpa till extra omsorg och service kan övergå till ett system där omsorgsinsatserna inte styrs av behovet. Samma avståndstagande gentemot möjligheten att utöka sina omsorgsinsatser utifrån ett intresse att unna sig lite extra förekom i flera andra intervjuer. Ingen av intervjupersonerna använde jämförelsen att de boende var vuxna och därför måste acceptera att någon annan betalade mer och då fick mer av personalens tid, utan frågan relaterades till ett oönskat klassamhälle där den rike fick bättre omsorg än den fattige. En fråga är naturligtvis om detta ställningstagande skulle se annorlunda ut i kommuner där köp av tilläggstjänster, subventionerade med rut-avdrag,är mer omfattande än i de undersökta kommunerna.

\section{Internt konstruerad gemenskap med undantag}

Vinjett A konstruerades primärt för att undersöka om vänskap mellan två väninnor kan åberopas som ett arrangemang som äldreboendet ska bidra till att förverkliga, men kom i intervjuerna helt att tolkas som en fråga om orättvis särbehandling.

Kategorin väninnor är extern i förhållande till äldreomsorgen och till de funktionsnedsättningar som en individ har. För väninnor som inte bor på särskilt boende skulle situationen ovan antagligen relateras till normer om intressen och närheten inom bekantskapen. Inte i någon av våra 
intervjuer togs möjligheten att upprätthålla eller reproducera denna typ av vänskap som utgångspunkt, vilket vi tolkar som att de två sågs som medlemmar av den interna kategorin "väninnor inom boendets gemenskap".

I samtliga intervjuer beskrevs situationen som ett problem som personalen behövde åtgärda. Två kvinnor på boendet genomförde en aktivitet som en tredje inte fick ta del av. Ingen argumenterade för att utflykterna borde ses som en typ av individanpassad och önskestyrd tillvaro som Signe inte hade med att göra, det vill säga en situation som liknade valet att äta lax på smörgåsen. Detta trots att flera intervjupersoner kommenterade betydelsen av att lyssna på individens önskemål om hur den enskilda tiden med kontaktpersonen skulle användas.

En vanlig reaktion, i synnerhet bland de boende, var att beskriva arrangemanget som en orättvisa. Inger, boende på Norrgården, kommenterade fallet som att "det är inte rätt" och motiverade ställningstagandet med att "de ska låta alla åka, även om de inte kan ta alla på en gång". När intervjuaren förklarade att det handlade om att två väninnor ville åka på egen hand, replikerade hon: "så kan man väl inte göra" och tillade: "De måste gå över... så att det inte drabbar några." Om inte Signe skulle följa med varje gång så kunde väninnorna kanske turas om att åka, eller så kunde boendet ordna kollektiva utfärder till museet. I diskussionerna som följde vinjetten om Signe och väninnorna framförde flera intervjupersoner förslaget att personalen skulle försöka "få in" Signe i de andra kvinnornas vänskapsrelation. I den kontext som äldreboendet utgjorde uppfattades grupperingar som provocerande, eftersom de skapade en form av olikhet gentemot de som var utanför grupperingen. Om två boende ville göra en utflykt ihop uppstod därför en situation som personalen behövde hantera genom olika pedagogiska knep. Kajsa, personal på Östergården såg inledningsvis inga hinder för att Signe skulle följa med de två andra kvinnorna:

Då skulle väl Signe kunna åka med ändå, det kan ju bli en väninna. De behöver ju inte vara väninnor för att åka. Alltså (Kajsa, omsorgspersonal).

När en annan intervjudeltagare kommenterade att de två andra kvinnorna kanske inte ville att Signe skulle följa med, svarade Kajsa:

Men då kan ju Signe få åka med sin kontaktperson själv på en utflykt tycker jag. Kan de två ha trevligt. Eller försöka att para ihop de där tre, det går kanske jättebra (Kajsa, omsorgspersonal).

I några fall menade intervjupersonerna också att de två väninnorna agerade olämpligt, exempelvis uttryckte enhetschefen på Västergården att situationen nästan utgjorde en slags mobbning och $\mathrm{i}$ intervjun med en personalgrupp på Östergården resulterade vinjetten $\mathrm{i}$ en diskussion om uteslutande relationer på boendet som personalen måste bidra till att bryta. I något fall ifrågasatte personal att två personer över huvudtaget skulle åka till museum när fem lika väl kunde göra det. Boendets gemenskap och resurser 
utgjorde den självklara utgångspunkten.

Ett tydligt resultat från intervjuerna var att vänskap inte utgjorde skäl att låta de två kvinnorna åka utan en tredje deltagare, men funktionsnedsättningar kunde däremot vara ett legitimt skäl för ett sådant arrangemang. Så här uttryckte sig exempelvis enhetschefen på Norrgården:

Carina (enhetschef): För att hon också ska ha möjlighet att följa med ifall hon vill det. $\mathrm{Nu}$ berättar du inte om hur, om det är rullstol och så vidare men jag hade verkat för att hon skulle följa med på samma runda.

Intervjuare: $\mathrm{Mm}$, även om de här två andra kvinnorna inte vill det.

Carina (enhetschef): Ja då hade jag försökt övertala faktiskt.

Ett liknande ställningstagande uttryckte Siv, boende på Östergården, och när intervjuaren hänvisade till de bådas vänskapsförhållandet svarade hon:

Det ska ju inte bero på om man är väninnor. Däremot är det ju väldigt svårt om de är olika sjuka, olika handikapp, men inte för att man är väninnor om det gäller från ett boende, det kan jag inte se att... (Siv, boende).

Reservation om funktionsnedsättningar och demens nämndes i flera intervjuer. Det var bara godtagbart att boende fick stanna hemma om det var på grund av deras sjukdomstillstånd, eller om den som lämnades hemma inte gick ihop med de övriga. I en intervju motiverade två närstående denna position med hänvis- ning till att äldreboendet är "en kollektiv miljö". Samtidigt kommenterade de att deras egna mödrar var vänner på boendet och att andra säkert kunde uppfatta sig som uteslutna från deras gemenskap. Grundproblemet, menade de närstående, var att äldreboendet utgjorde en förminskande värld där de boende uppfattade sig berörda och drabbade av triviala saker i den nära omgivningen. Med denna utgångspunkt, som egentligen var fel, blev det enda legitima skälet för uteslutning om den boende hade någon typ av problem som gjorde utfärderna besvärliga.

Under intervjuerna handlade referensen till sjukdom inte bara om att de två väninnornas besök skulle få en annan karaktär om exempelvis en person som var förvirrad och bråkig följde med, utan även om de praktiska besvären med framkomlighet.

Det som är intressant med argumentationen i ett lite större perspektiv är att de boendes funktionsnedsättningar ses som ett legitimt hinder för deltagande i aktiviteter. Detta trots att det faktiskt är funktionsnedsättningarna som utgör grunden för att en person överhuvudtaget beviljas plats på ett äldreboende.

\section{Avslutande diskussion}

Vad innebär en individanpassad äldreomsorg för de som bor på särskilda boenden? Vad innebär likvärdighet? I den här studien har vi närmat oss dessa frågor empiriskt, genom deltagande observationer och intervjuer med personer som har en direkt vardaglig erfarenhet av äldreomsorgens särskilda boenden - som omsorgsta- 
gare, närstående, personal och chefer. Vårt intresse har varit att undersöka vilka jämförelser dessa personer använder när de resonerar och värderar betydelser av individanpassad och likvärdig omsorg, samt att visa hur förekommande olikheter ramas in.

Analysen visar att spänningar som uppstår i förhållande till mål om att ge individanpassad och likvärdig omsorg inte bara kan förstås principiellt; handlingar och arrangemang ramas in, rättfärdigas och ifrågasätts med utgångspunkt i olika typer av lokalt förankrade referenser. En situation där personalen köper in lyxig mat till en av de boende som denne sedan äter i matrummet inför de andras suktande blickar kan beskrivas som ett oacceptabelt fall av ojämlik äldreomsorg. Men fallet kan också ses som ett exempel på hur personalen lyckas få en av de boende att använda sina pengar till att utvecklas och öka sin livskvalitet genom att frångå ett invant, men begränsande livsmönster.

De personer vi intervjuade slöt upp kraftfullt omkring målet om en individanpassad äldreomsorg. Målet om likvärdighet framstod inte som lika etablerat och understött, i synnerhet inte när det relaterades till äldreomsorgens förflutna, där de boende behandlades lika men som ett kollektiv på institutionens villkor. Intervjupersonerna var också beredda att acceptera och understödja olikheter i levnadsvillkor, när dessa inte ansågs "drabba" andra på boendet. Givet att antalet personer som intervjuades var få, framträdde en skillnad där chefer och personal var mer benägna än boende att ge målet om individanpassning företräde i förhållande till målet om likvärdighet.
Parallellt med acceptansen för olikhet uttrycktes ett starkt avståndstagande från en omsorg som reproducerar ojämlikhet baserad på klasstillhörighet och ekonomiska förhållanden, det vill säga till den typ av ojämlikhet som Mirjam Katzin diskuterar i sin artikel om valfrihet i detta temanummer. Äldreomsorgen fick enligt de intervjuade inte göra skillnad mellan fattig och rik: inte sill och potatis till den ena och entrecote till den andra. Under intervjuerna beskrevs förekomsten av olikheter som just skulle kunna ses som en sådan skillnad, men som istället ramades in på annat sätt. Förekomsten av alternativa inramningar kan därmed ses som ett sätt att upprätthailla ett ställningstagande mot social ojämlikhet $i$ ett sammanhang där individuella lösningar och olikheter är en del av vardagen.

Studien visar att med undantag från referenser till personens historia och status som hyresgäst använder personal, boende och närstående framför allt interna referenser som navigationsinstrument när de resonerar om likvärdig respektive individanpassad omsorg på äldreboenden. Samtidigt som dessa jämförelser hänvisar mot idéer om en positiv gemenskap och möjligheter till utveckling på boendet finns det en risk att de interna referenserna bidrar till att omsorgstagarnas problem framstår som orsakade av individen själv.

Begränsningar som kopplas till funktionsnedsättningar i hög ålder uppfattas som livsvillkor, som "naturliga" hinder i relation till de aktiviteter som i allmänhet är möjliga för de boende att delta i.En av de externa referenser som ofta används inom 
äldreomsorgen handlar om att personen ska kunna leva som tidigare (McCormack, et al., 2012; Erlandsson, 2014). Som framgått är den referensen svag, eftersom den kan avfärdas med hänvisning till de funktionsnedsättningar som föranlett och följt flytten till boendet. Sådana hänvisningar till vad som varit möjligt tidigare men inte var det numera, var vanliga $i$ våra intervjuer. Det var den tilltagande ohälsan som sågs som begränsande, inte samhällets bristande stöd för äldre personer med funktionsnedsättningar.

En fråga är då om det är möjligt att identifiera externa kategorier och kontexter som kan bidra till att användningen av de interna referenserna balanseras upp. I artikelns inledning kommenterade vi funktionshinderpolitikens externa jämförelser, som uttryckts med mål av typen: "Möjlighet att leva som andra" (SOU 2008:77) och ofta preciseras till att avse jämförelser med personer i motsvarande ålder (Jönson \& Taghizadeh, 2009). Inom den sociala modellen, som utvecklats inom funktionshinderpolitiken, betraktas funktionshinder som orsakade av samhällets bristande anpassning till och stöd för personer med olika funktionsnedsättningar (Tideman, 2000). Inom funktionshinderpolitiken har, som Erlandsson konstaterar i detta temanummer, mål om aktivitet och delaktighet handlat om att göra samhället tillgängligt medan samma mål inom omsorgen kommit att handla om själva omsorgskontexten. Äldreomsorgen tenderar med detta att bli sin egen värld, där frågor om likvärdighet och rättvisa mäts med hänvisning till andra med omsorgsbehov, andra omsorgstagare eller andra på samma boende.
Kan den som bor på äldreboende hävda att han eller hon ska kunna leva som andra pensionärer, dvs. som personer som inte har omfattande funktionsnedsättningar? Vad är normalt för en person i den åldern? Bör den som bor på ett särskilt boende för äldre sträva efter de villkor som gäller för pensionärer i allmänhet? Eller som yngre personer med funktionsnedsättningar? Kan hänvisningar till externa referenser medföra förnekanden av skröplighet och individens anpassning till det lokala sammanhanget och gemenskapen på boendet?

Denna typ av svåra frågor om jämförelser, rättigheter och normbildning har under lång tid diskuterats inom forskning om yngre personers funktionsnedsättningar och bland aktivister inom handikapprörelsen (Tideman, 2000). Vi menar därför att just denna forskning och aktivism kan användas som inspirationskälla och förebild för äldreomsorgen. Det finns också exempel på hur kraftfulla referenser till externa kategorier och kontexter kan bli inom äldreomsorgen. Kategorin hyresgäst står inte bara som en alternativ benämning till den interna kategorin "patient" utan medför, som framgår i Per Norbergs artikel inom detta temanummer, rättigheter som gäller för "andra hyresgäster".

Livet på ett äldreboende innebär ytterst speciella förutsättningar, där omsorgskontexten riskerar att skapa sin egen interna logik med egna förgivettagna lösningar. Denna studie visar att en kritisk analys utifrån referensgruppsteorin gör det möjligt att ifrågasätta arrangemang och lösningar som annars riskerar att bli till oemotsagda sanningar. 


\section{Referenser}

Berglund, A.-L. (2007). Satisfaction with caring and living conditions in nursing homes: Views of elderly persons, next of kin and staff members. International Journal of Nursing Practice, 13(1), 46-51.

Björklund, J. \& Westerholm, B. (2009). Äldre par måste garanteras den sista tiden tillsammans. Dagens Nyheter, 2009-11-19.

Bolmsjö, I. Å., Sandman, L., \& Andersson, E. (2006). Everyday Ethics in the Care of Elderly People. Nursing Ethics, 13(3), 249-263.

Edvardsson, D., Winblad, B., \& Sandman, P. O. (2008). Person-centred care of people with severe Alzheimer's disease: current status and ways forward. The Lancet Neurology, 7(4), 362367.

Emerson, R. M., Fretz, R. I., \& Shaw, L. L. (1995). Writing Ethnographic Fieldnotes, . Chicago: University of Chicago Press.

Erlandsson, S. (2014). Hjälp att bevara eller förändra? Åldersrelaterade diskurser om omsorg, stöd och service. (Diss.) Stockholms universitet.

Goffman, E. (1974). Frame analysis: An essay on the organization of experience New York: Harper \& Row.

Gubrium, J., \& Holstein, J. (1997). The new language of qualitative method. New

York: Oxford University Press.

Harnett, T. \& Jönson, H. (2010). That's not my Robert! Identity maintenance and other warrants in family members' claims about mistreatment in old-age care. Ageing \& Society, 30(04), 627-647.

Jönson, H. \& Taghizadeh Larsson, A. (2009). The Exclusion of Older People in Disability Activism and Policies - A Case of Inadvertent Ageism? Journal of Aging Studies, 23, s. 69-77.

Koren, M. J. (2010). Person-centered care for nursing home residents: the culture-change movement. Health Affairs, 29, 2, 312-317.

McCormack, B., Roberts, T., Meyer, J., Morgan, D., \& Boscart, V. (2012). Appreciating the 'person' in long-term care. International Journal of Older People Nursing, 7(4), 284-294.

Merton, R. K., \& Kitt, A. (1950). Contributions to the theory of reference group behavior. Glencoe, Illinois: Free Press.

Noddings, N. (1999). Care, Justice, and Equity. In M. S. Katz, N. Noddings \& K. A. Strike (Eds.), Justice and Caring. The Search for Common Ground in Education. New York: Teachers College Press.

Nolan, M., Davies, S., \& Brown, J. (2006). Transitions in care homes: towards relationshipcentred care using the 'Senses Framework'. Quality in Ageing and Older Adults, ,7(3), 5-14.

Potter, J. (1996). Representing Reality: Discourse, Rhetoric and Social Construction. London:Sage Publications.

Rawls, J. (1971). A theory of justice. Cambridge: Harvard University Press.

Rebas, K. (2014). Finns kvalitet utan egenmakt? Ystads Allehanda, 2014-02-14.

Runciman, W. C. (1966). Relative deprivation \& social justice: study attitudes social inequality in 20th century England. London: Routledge \& Kegan Paul.

Suhonen R., Gustafsson M.-L., Katajisto J., Välimäki M. \& Leino-Kilpi M. (2009). Nurses' Perceptions of Individualized Care. Journal of Advanced Nursing 66: 1035-1046.

SOU (1991:46). Handikapp, välfärd, rättvisa. Betänkande av 1989 års Handikapputredning.

Socialstyrelsen (2011). Bostad i särskilt boende är den enskildes hem.

Socialutskottets betänkande 2009/10:SoU18. Värdigt liv iäldreomsorgen.

Szebehely, M. \& Trydegård, G.-B. (2014). Hur mycket självbestämmande ryms det i skälig levnadsnivå? Socialtjänstlagens visioner och äldreomsorgens realiteter. I U. Pettersson (Red.), Tre decennier med socialtjänstlagen utopi, vision, verklighet. Malmö: Gleerups. 
Tideman, M. (2000). Normalisering och kategorisering: Om handikappideologi och välfärdspolitik $i$ teori och praktik för personer med utvecklingsstörning. Göteborgs universitet.
Vabø; M. \& Szebehely, M. (2012). A caring state for all older people. I A. Anttonen, L. Häikiö, \& K. Stefánsson (Red.). Welfare state, universalism and diversity. Cheltenham. Edward Elgar Publishing.

\section{Summary}

\section{Herring and potatoes for some and tenderloin for others? Equality and individualization in residential care for older people}

Residential care facilities aim at providing individualized care but operate according to laws and goals of social policy that prescribe equal treatment of all citizens. Focusing on the tension between these two goals, the aim of this article was to analyse how views of equality and individualization unfold in everyday situations in long-term care facilities for older persons. Older people who live at care facilities are regarded as tenants and have private apartments, but share much of their daily lives with other residents. The empirical material consisted of ethnographic data and interviews with residents, family members, staff and managers at four long-term care facilities for older people. Using concepts from reference group theory, the analysis focused on what kinds of comparisons were invoked in claims about individual and equal care arrangements. The analysis revealed that the goal of providing individualized care was strongly supported and in some cases regarded as more important than equal treatment. At the same time, participants in the study declared that arrangements that expressed social inequality should not occur. Following this, they tended to place occurring and accepted differences outside a framework that referred to social inequality. The study revealed that concepts like justice and equality tended to be constructed internally, in relation to the context of care, and to a lesser extent based on references to the world outside care. In the article this tendency is related to the bordering field of disability, where justice and equality have been constructed in comparison to external reference groups. 